\title{
Selected determinants of attitude towards surgery in abdominal aortic aneurysm patients
}

\author{
Wybrane cechy determinujące postawę pacjentów z tętniakami aorty \\ brzusznej wobec operacji
}

\author{
Michał-Goran Stanišić르, Teresa Rzepa², Alicja Gawrońska², Maciej Putowski \\ ${ }^{1}$ Department of General and Vascular Surgery, Poznan University of Medical Sciences, Poland \\ ${ }^{2}$ University of Social Sciences and Humanities, Department of Poznan, Poland \\ ${ }^{3}$ Medical University of Lublin, Poland
}

Neuropsychiatria i Neuropsychologia 2017; 12, 2: 61-64

Address for correspondence:

Maciej Putowski

Medical University of Lublin

Aleje Racławickie 1

20-059 Lublin, Poland

e-mail: putowski.maciek@gmail.com

phone: +48502321 226

\section{Abstract}

Aim of the study was to find out whether there is a correlation between the attitude to surgery and self-efficacy, health locus of control, and own life quality assessment in abdominal aortic aneurysm patients. Material and methods: Thirty-six consecutive asymptomatic AAA patients qualified for elective surgery were examined. The group included 11 women and 25 men, aged 49-85 years. Four scales were applied: the Generalised Self-Efficacy Scale (GSES), the Satisfaction With Life Scale (SWLS), the Multidimensional Health Locus of Control Scale (MHLC), and a scale to find the attitude to surgery, in which " -10 " stands for the maximally negative attitude, "0" - neutral, and " +10 " - maximally positive.

Results: Correlations between attitude towards surgery, type of surgical procedure, and repeatability of hospitalisation proved to be statistically insignificant $\left(\chi^{2}\right.$ test values were, respectively: $9.773, p<0.878$; 6.353 , $p<0.608)$. It was found that on average the attitude to surgery varied $(S D=6.6)$; however, it was generally positive and oscillated around the average $(M=6.5)$. The mean value of self-efficacy was high $(M=33.64$, $S D=4.75)$. External personal health locus of control was predominant $(M=26.44, S D=4.675)$, the runner-up was internal health locus of control $(M=25.08$, $S D=4.02)$, and the last one was external impersonal health locus of control (fate/chance) $(M=24.03$, $S D=4.66)$. The mean assessment of one's own life quality proved to be above average $(M=23.25)$ but varied $(S D=6.65)$.

Conclusions: The higher the personal resources (such as self-efficacy, the assessment of own life quality, and the internal health locus of control), the more positive the attitude towards surgery. External personal health locus of control in patients before surgery is predominant, which indicates the role of medical professionals in communication with patients.

Key words: abdominal aortic aneurysm (AAA), personal resources, quality of life.

\section{Streszczenie}

Celem pracy było zbadanie, czy istnieje związek między postawą pacjentów z tętniakiem aorty brzusznej (AAA) wobec operacji a skutecznością własną, umiejscowieniem kontroli zdrowia oraz własną oceną jakości życia.

Material i metody: Badaniem objęto 36 pacjentów z bezobjawowym AAA zakwalifikowanych do zabiegu chirurgicznego. W grupie było 11 kobiet i 25 mężczyzn w wieku 49-85 lat. Zastosowano 4 skale: Skalę Uogólnionej Wtasnej Skuteczności (GSES), Wielowymiarowa Skale Umiejscowienia Kontroli Zdrowia (MHLC), Skale Satysfakcji z Życia (SWLS) oraz skalę służącą do określenia stosunku do operacji, gdzie „-10” oznacza maksymalnie negatywne podejście, „0” - średnie, a „, +10 ” - maksymalnie pozytywne.

Wyniki: Nie stwierdzono istotnych statystycznie zależności pomiędzy postawa a rodzajem operacji ani ponownymi hospitalizacjami (wartości testu $\chi^{2}$ wynosiły odpowiednio: 9,773, $p<0,878 ; 6,353, p<0,608$ ). Stwierdzono, że podejście do operacji było zróżnicowane $(S D=6,6)$, jednakże było na ogół pozytywne i oscylowało wokól średniej $(M=6,5)$. Srednia wartość własnej skuteczności była wysoka $(M=33,64, S D=$ $4,75)$. Dominowało zewnętrzne umiejscowienie kontroli zdrowia (HLoC) $(M=26,44, S D=4,675)$, następnie wewnętrzne HLoC $(M=25,08, S D=4,02)$, a najniższe wartości osiągnęło HLoC zależne od przypadku $(M=24,03, S D=4,66)$. Średnia ocena jakości życia była ponadprzeciętna $(M=23,25)$, jednakże zróżnicowana $(S D=6,65)$.

Wnioski: Im większe zasoby osobiste, takie jak własna skuteczność, ocena własnej jakości życia i wewnętrzna kontrola zdrowia, tym bardziej pozytywne nastawienie do operacji. U pacjentów przed zabiegiem chirurgicznym największe znaczenie ma zewnętrzne umiejscowienie kontroli zdrowia, co wskazuje na istotną rolę komunikacji lekarzy z pacjentami.

Słowa kluczowe: tętniak aorty brzusznej (AAA), zasoby osobiste, jakość życia. 


\section{Introduction}

Abdominal aortic aneurysm is the $12^{\text {th }}-13^{\text {th }}$ cause of death in the male population. Abdominal aortic aneurysm tends to be asymptomatic almost until its rupture. Elective surgery of abdominal aortic aneurysm is done when its diameter exceeds $55 \mathrm{~mm}$ in men and $52 \mathrm{~mm}$ in women (Moll et al. 2011). Currently, there are two approaches to abdominal aortic aneurysm surgical treatment. Open surgery, practised for 70 years, has been a successful way to eliminate an aneurysm from the circulatory system. Due to the cardiological risks connected with open surgery, in the past some patients were not qualified for elective operations and underwent surgical treatment only in the case of rupture symptoms. Introduction of endovascular aneurysm repair (EVAR) at the turn of the 1980s and 1990s made it possible to include more patients in elective surgery. Despite improved techniques of open surgery and cardiological risk reduction following introduction of EVAR, aneurysm treatment is still connected with a relatively high risk of postoperative complications, including 30/90-day deaths (Moll et al. 2011). Abdominal aortic aneurysm is diagnosed most often accidentally, during a routine USS of the abdominal cavity performed for some other reason. Patients learn about an asymptomatic disease that is potentially life-threatening, and are referred to specialist treatment and informed about the risks related to the disease. Some of the patients are referred to surgical treatment as early as during the first appointment with the consulting physician, which leads to experiencing cognitive dissonance by the patients because their disease is asymptomatic. In view of the insufficient amount of time that the consulting doctor can spend talking to the patient during the appointment, as well as the generally scarce knowledge about the disease, the patients are subject to a number of psychological reactions aimed at coping with the news of the need for surgical treatment. Additionally, myths connected with open surgery risks are increasingly circulated, which leads to patients insisting on EVAR even when it is not justified.

The resulting mental and emotional state of the patient requires activation of personal resources needed to effectively cope with difficult situations in life, i.e. facing sudden news of a fatal disease (Newman and Newman 2017; Eriksson and Lindström 2007). The resources include the particularly important dispositions such as self-efficacy and health locus of control because they enable patients to cope with the stress resulting from the sudden news of a serious disease. Its adaptive value is reinforced by a positive assessment of one's life quality.

Self-efficacy is based on the conviction that one is able to meet one's objectives, i.e. to carry out one's tasks even in unforeseeable and stressful conditions (Schwarzer 2014). Health locus of control is understood as a generalised expectation that any events in life are a result of either external forces or one's own efforts and personal control (Deci and Ryan 2010). Internal health locus of control is connected with taking personal responsibility for one's health. However, health locus of control may also be external; patients may see it as dependent either on other people (especially health professionals and family) or on one's fate or chance (Lefcourt 2014; Peterman 2000). As for their life quality assessment, it relates to a set of factors such as physical health, mental condition, degree of independence, relations with the people around them, and functioning in their social and occupational roles (Lefcourt 2014; Pavot and Diener 2008).

The described psychological categories underlie the mechanisms of coping with life challenges, such as sudden news of a fatal disease and the need to undergo surgery. Therefore, it was decided to find out whether there is a correlation between the attitude to surgery and self-efficacy, health locus of control, and own life quality assessment in abdominal aortic aneurysm patients. The study also included verification of the correlation between attitude to surgery and the kind of surgical procedure, and the repeatability of hospitalisation.

\section{Methods}

After obtaining consent from the appropriate local regulatory board, in the period from March to October 201436 consecutive asymptomatic abdominal aortic aneurysm patients were examined. All these patients had been qualified for surgical treatment and hospitalised for elective surgery. The group included 11 women and 25 men, aged 49 to 85 years $(M=70.86$, $S D=8.3)$. Twenty-five patients $(69.4 \%)$ were married, six $(16.7 \%)$ - widowed, four $(11.1 \%)$ - single, and one person refused to provide this information. Nineteen persons $(52.8 \%)$ were hospitalised for the first time, and 17 (47.2\%) for the second or more times. In the case of 18 patients $(50 \%)$, open aortic repair (OAR) was applied, in the case of 10 - EVAR (27.8\%), whereas operations on eight patients $(22.2 \%)$ 
were temporarily postponed due to the need to improve the cardiological condition before elective surgery.

In view of the purpose of the study, four scales were applied (Juczyński 2009), which were completed - with the help of the researcher - by the patients awaiting elective surgery in the clinical hospital. The tests were:

1. Generalised Self-Efficacy Scale (GSES), composed of 10 statements and measuring the level of general personal conviction regarding the individual's efficacy in handling tough situations.

2. Satisfaction With Life Scale (SWLS), composed of five statements and measuring the generalised feeling of satisfaction with life so far.

3. Multidimensional Health Locus of Control scale (MHLC), composed of 18 statements and aimed at specifying their expectations in three aspects of health locus of control (Pavot and Diener 2008). Thus, the study participant indicates whether their own health is controlled: 1) by them (internal aspect); 2) by other individuals, especially health professionals (external personal aspect); or 3) by fate/chance (external impersonal aspect).

4. A simple scale was applied to find the attitude to surgery, where " -10 " stands for the maximally negative attitude, " 0 " - neutral, and " +10 " - maximally positive.

Scales 1, 2, and 3 were used for measuring mental dispositions being part of personal resources (self-efficacy, health locus of control, life quality assessment), and scale 4 - to specify the kind and intensity of one's attitude to surgery.
The statistical analysis of the results was done by means of IBM SPSS Statistics 22 software. To assess the normality of distribution of the analysed variables, the Kolmogorov-Smirnov test was applied for one sample. Because it transpired that the distribution of results was not normal, Spearman's correlation coefficient rho and $\chi^{2}$ test were applied to specify the correlation strength between the variables.

\section{Results}

Correlations between attitude towards surgery, type of surgical procedure, and repeatability of hospitalisation proved to be statistically insignificant $\left(\chi^{2}\right.$ test values were, respectively: 9.773 , $p<0.878 ; 6.353, p<0.608)$. It was found that on average the attitude to surgery varied $(S D=6.6)$; however, it was generally positive and it oscillated around the average $(M=6.5)$. The mean value of self-efficacy was high $(M=$ 33.64, $S D=4.75)$. External personal health locus of control was predominant $(M=26.44$, $S D=4.675)$, the runner-up was internal health locus of control $(M=25.08, S D=4.02)$, and the last one was external impersonal health locus of control (fate/chance) ( $M=24.03$, $S D=4.66$ ). The mean assessment of one's own life quality proved to be above average $(M=$ $23.25)$ but varied $(S D=6.65)$ (Table 1$)$.

\section{Discussion}

The study results show that in the case of abdominal aorta aneurysm patients who learn they have a potentially fatal disease and are

Table 1. Correlations between attitude towards surgery and mental dispositions (rho)

\begin{tabular}{|c|c|c|c|c|c|c|}
\hline & Self-efficacy & $\begin{array}{l}\text { Internal } \\
\text { health locus } \\
\text { of control }\end{array}$ & $\begin{array}{l}\text { External } \\
\text { personal } \\
\text { health locus } \\
\text { of control } \\
\text { (other } \\
\text { people) }\end{array}$ & $\begin{array}{l}\text { External } \\
\text { impersonal } \\
\text { health locus } \\
\text { of control } \\
\text { (fate/chance) }\end{array}$ & Quality of life & $\begin{array}{l}\text { Attitude } \\
\text { to surgical } \\
\text { treatment }\end{array}$ \\
\hline Self-efficacy & - & $.405^{\star}$ & .158 & .269 & $.434^{\star \star}$ & $.470^{\star *}$ \\
\hline $\begin{array}{l}\text { Internal health locus } \\
\text { of control }\end{array}$ & $.405^{\star}$ & - & $.408^{*}$ & $.587^{\star \star}$ & .270 & .276 \\
\hline $\begin{array}{l}\text { External personal } \\
\text { health locus of control } \\
\text { (other people) }\end{array}$ & .158 & $.408^{*}$ & - & $.623^{\star *}$ & $.429^{\star *}$ & $.366^{*}$ \\
\hline $\begin{array}{l}\text { External impersonal } \\
\text { health locus of control } \\
\text { (fate/chance) }\end{array}$ & .269 & $.587^{\star *}$ & $.623^{* *}$ & - & $.399^{\star}$ & .301 \\
\hline Quality of life & $.434^{\star *}$ & .270 & $.429^{\star *}$ & $.399^{\star}$ & - & $.466^{\star *}$ \\
\hline $\begin{array}{l}\text { Attitude to surgical } \\
\text { treatment }\end{array}$ & $.470^{\star *}$ & .276 & $.366^{\star}$ & .301 & $.466^{\star \star}$ & - \\
\hline
\end{tabular}


required to make a decision on surgery, it is necessary to pay particular attention to their personal resources. This in particular regards mental dispositions that are correlated with a positive attitude towards surgery. It is known that such a positive attitude has a beneficial effect on the treatment process and recovery (Zotti et al. 2007; Janowski and Steuden 2009; Szramka-Pawlak et al. 2014), and in the case of this disease - on making a decision about surgery (Dalman and Mell 2014). It was found that the higher the self-efficacy, the higher the assessment of one's own life quality $(p<0.01)$, and the higher the internal health locus of control $(p<0.05)$, the more positive the attitude towards surgery, indicating a significant role of medical professionals and family.

These findings can be explained by referring to human behaviour in a challenging life situation, in this case sudden news of a fatal disease (Baune et al. 2011; Kościelak 2010; Mall et al. 2007). It seems obvious that the higher the patient's assessment of their own life quality, the higher the motivation to undergo treatment and to cope with the disease being a negative life event (Stanisić and Rzepa 2012; Kościelak 2010). Then the event (disease) is treated like a challenge, which activates personal resources in order to take an effective decision (Janowski and Steuden 2009; Stanisić and Rzepa 2012). Therefore, it is important to refer to self-efficacy and the conviction of individual responsibility for one's health (Kościelak 2010). Concurrently, the patient is aware that effective solving of his or her problem depends on the actions of medical professionals and on his or her family's support (Dalman and Mell 2014). Therefore, when communicating the news of a life-threatening abdominal aortic aneurysm, the physician (or psychologist) should strongly refer to the ultimate values: the patient's life and health. Thus, the communicated message will additionally motivate the patient to undergo surgical treatment and will reinforce the patient's conviction that the disease should be treated like a challenge, and will help activate the resources needed to change the unfavourable life situation.

\section{Conclusions}

The higher the personal resources (such as self-efficacy, the assessment of one's own life quality, and the internal health locus of control), the more positive the attitude towards surgery. External personal health locus of control in patients before surgery is predominant, which indicates the role of medical professionals in communication with patients. Skilled use of the patient's personal resources in patients before elective surgery of abdominal aortic aneurysm may lead to improvement of the patient's motivation, creating a positive attitude to the surgery.

\section{References}

1. Baune BT, Unwin SJ, Quirk F, et al. Neuropsychiatric symptoms in patients with aortic. PLoS One 2011; 6: e22632.

2. Dalman RL, Mell M. Management of asymptomatic abdominal aortic aneurysm. Available at: www.uptodate.com/ contens/management-of-asymptomatic-abdominalaortic-aneurysm [Accessed: 1 September 2017].

3. Deci EL, Ryan RM. Self-determination. John Wiley \& Sons, Inc 2010.

4. Eriksson M, Lindström B. Antonovsky's sense of coherence scale and its relation with quality of life: a systematic review. J Epidemiol Community Health 2007; 61: 938-944.

5. Newman BM, Newman PR. Development through life: A psychosocial approach. Cengage Learning 2017.

6. Janowski K, Steuden S. Biopsychosocial aspects of health and disease. CPPP Scientific Press, Lublin 2009.

7. Juczyński Z. Narzędzia pomiaru w promocji i psychologii zdrowia. Pracownia Testów Psychologicznych, Warszawa 2009.

8. Kościelak R. Poczucie umiejscowienia kontroli i przekonania o własnej skuteczności w zdrowiu i chorobie. IMPULS, Kraków 2010.

9. Lefcourt HM. Locus of control: Current trends in theory \& research. Psychology Press 2014.

10. Mall Gd, Kesserwane R, Hennebry TA, et al. Anxiety disorders: Aortic aneurysm in the differential? Psychiatric Times 2007. Available at: www.psychiatrictimes.com/ articles/anxiety-disorders-aortic-aneurysym-in-thedifferential [Accessed: 10 August 2017].

11. Moll FL, Powell JT, Fraedrich G, et al. Management of Abdominal Aortic Aneurysms Clinical Practice Guidelines of the European Society for Vascular Surgery. Eur J Vasc Endovasc Surg 2011; 41: 1-58.

12. Pavot W, Diener E. The Satisfaction With Life Scale and the emerging construct of life satisfaction. J Posit Psychol 2008, 3: 137-152.

13. Peterman AH, Cella D. Quality of life. In: AE Kazdin (ed.), Encyclopedia of Psychology. Oxford University Press-American Psychological Association, Oxford 2000.

14. Schwarzer R. Self-efficacy: Thought control of action. Taylor \& Francis 2014.

15. Stanisić M. Rzepa T. Attitude towards one's illness vs. Attitude towards a surgical operation, displayed by patients diagnosed with asymptomatic abdominal aortic aneurysm and asymptomatic internal carotid artery stenosis. Int Ang 2012; 31: 376-385.

16. Szramka-Pawlak B, Dańczak-Pazdrowska A, Rzepa T, et al. Quality of life and optimism in patients with morphea. Appl Res Qual Life 2014; 9: 863-870.

17. Zotti AM, Balestroni G, Cerutti P, et al. Application of the General Perceived Self-Efficacy Scale in cardiovascular rehabilitation. Monaldi Arch Chest Dis 2007; 68: 178-183. 